\title{
Arthrinium globosum, a new hyphomycetous species
}

\author{
PENTTI KOSKELA
}

KOSKELA, P. 1983: Arthrinium globosum, a new hyphomycetous species. - Karstenia 23: $13-14$

A new species of Hyphomycetes (Deuteromycotina), Arthrinium globosum Koskela, is described from Finland. It resembles most closely $A$. sphaerospermum Fuckel, from which it differs in having larger, more globose conidia with a hyaline rim in side view. A. globosum has been obtained only on Cyperaceae.

Pentti Koskela, National Public Health Institute, P.O. Box 267, SF-70101 Kuopio, Finland

Arthrinium globosum Koskela n.sp.

Coloniae compactae, discretae, pulvinatae, rotundataevel ovales, atrobrunneae. Mycelium partim superficiale et partim in substrato immersum. Mycelium superficiale ex hyphis ramosis et anastomosantibus septatis, hyalinis vel olivaceo-brunneis, levibus, 2-7 $\mu \mathrm{m}$ crassis compositum. Conidiophora ex cellulis subsphaericis vel lageniformibus, 4-7 $\times 3-5 \mu \mathrm{m}$ oriunda, simplicia, erecta vel flexuosa, cylindrica, incolorata, levia, ad $100 \mu \mathrm{m}$ longa, 3-4 um crassa, septis tranversis brunneis vel atrobrunneis praedita. Conidia globosa vel subsphaerica, levia, a faciebus brunnea, a lateribus hyalinea, 8-10 $\times 7-9 \mu \mathrm{m}(9.0 \times 7.9 \mu \mathrm{m})$. Cellulae steriles nullae.

- Typus: Fennia, prov. Oulun Pohjanmaa, Muhos, Carex cespitosa L., 7.V.1972 Tauno Ulvinen (OULU).

Colonies compact, discrete, pulvinate, round to oval, dark brown. Mycelium partly superficial, partly buried in the substratum, composed of branched and anastomosing, septate, hyaline to olivaceous brown, smooth-walled hyphae, $2-7 \mu \mathrm{m}$ thick. Conidiophore mother cells subsphaerical to lageniform, 4-7 $\times 3-5$ $\mu \mathrm{m}$. Conidiophores simple, straight or flexuous, cylindrical, colourless except for the brown or dark brown, transverse septa, smooth-walled, up to 100 $\mu \mathrm{m}$ long, 3-4 $\mu \mathrm{m}$, bearing conidia laterally. Conidia globose or almost round, smooth-walled, brown in front view, hyaline in side view, 8-10 $\times 7-9 \mu \mathrm{m}(9.0$ $\times 7.9 \mu \mathrm{m})$. Sterile cells none.

\section{Discussion}

The new species resembles Arthrinium sphaerospermum Fuckel most closely of all the 21 Arthrinium species known earlier (Ellis 1965, 1976, Gjærum 1967, Pollack \& Benjamin 1969). A. globosum differs from that species in having larger, more globose conidia with a hyaline rim in side view (Figs. 1 and 2). The average dimensions of the conidia of $A$. sphaerospermum are $7.1 \times 6.1 \mu \mathrm{m}$. These species also have different host spectra, $A$. globosum has been obtained only on Cyperaceae and $A$. sphaerospermum mostly on Poaceae and occasionally on Cyperaceae and Juncaceae. Most of the 35 A. globosum collections are from central and northern Finland, Carex cespitosa serving as host in $60 \%$ of the cases (Koskela \& Peura 1983).

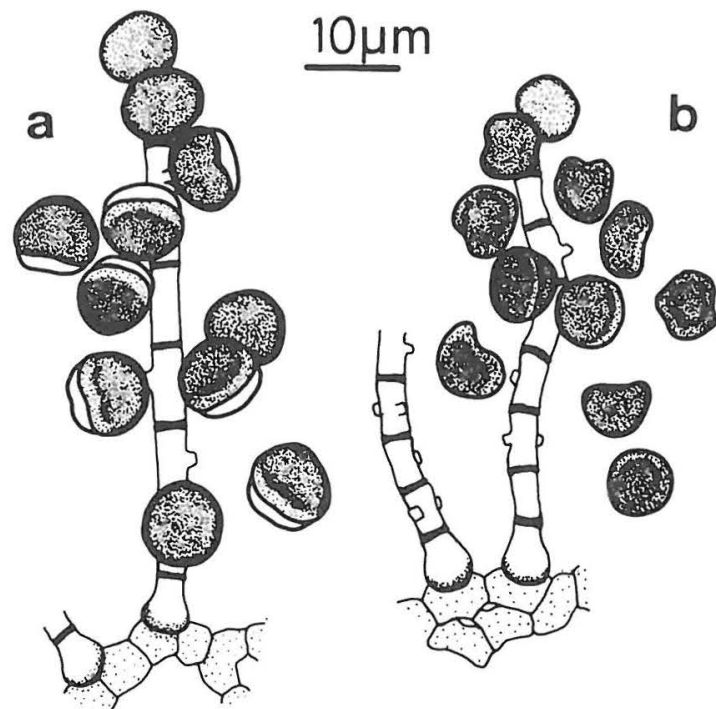

Fig. 1. Conidiophores and conidia of a) A. globosum, and b) A. sphaerospermum. 
Fig. 2. Size of conidia of Arthrinium globosum and $A$. sphaerospermum. Each point is based upon measurements of 25 conidia (Koskela \& Peura 1983).

A. globosum on Cyperaceae

A. sphaerospermum on Cyperaceae

$\odot$ A. sphaerospermum on Poaceae

$\Theta$ A. sphaerospermum on Juncaceae

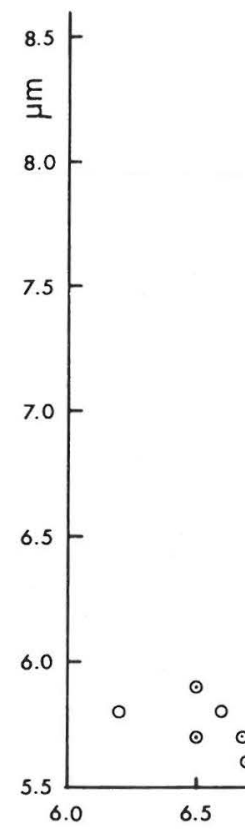

\section{References}

Ellis, M.B. 1965: Dematiaceous Hyphomycetes 6. - Mycol. Papers (103): 1-46.

- 1976: More Dematiaceous Hyphomycetes. - 507 pp. Kew, Surrey.

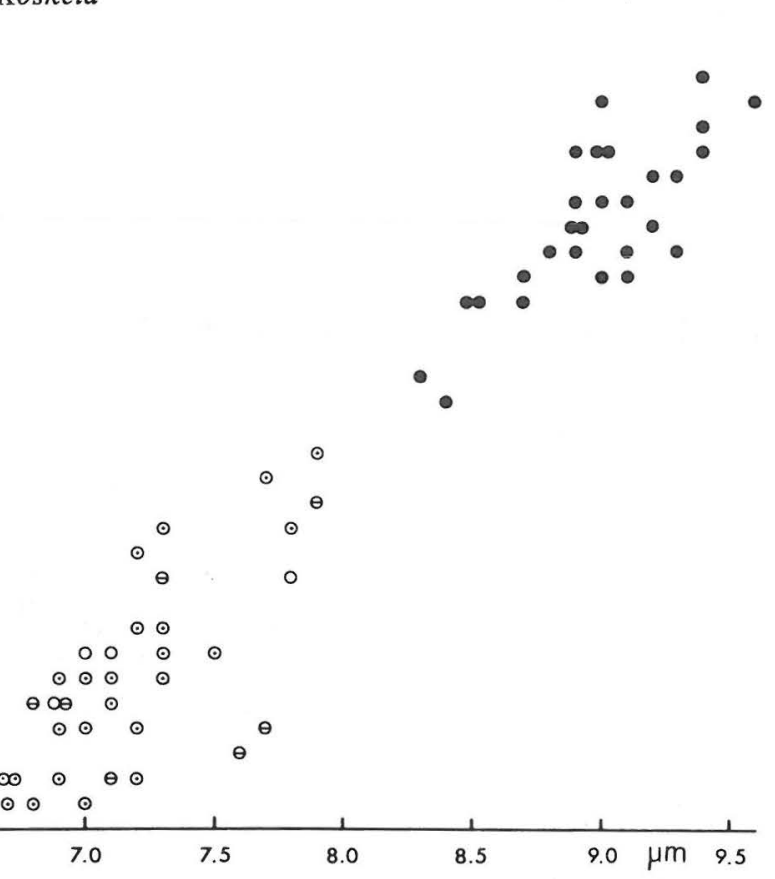

Gjæerum, H.B. 1967: Arthrinium morthieri, A. fuckelii n sp., and A. ushuvaiense. - Nytt Mag. Bot. 14: 1-6.

Koskela, P. \& Peura, R. 1983: The genus Arthrinium in Finland. - Manuscript.

Pollack, F.G. \& Benjamin, C.R. 1969: Arthrinium japonicum and notes on Arthrinium kamtschaticum. - Mycologia 61: $187-190$. 